\title{
INFLUENCE OF LIGHT ON PRYMNESIUM PARVUM GROWTH, TOXICITY AND MIXOTROPHY
}

\author{
Emanuela Fiori ${ }^{1}$ \\ Nayani K. Vidyarathna ${ }^{2}$ \\ Johannes A. Hagström ${ }^{2}$ \\ Rossella Pistocchi ${ }^{1}$ \\ Edna Granéli ${ }^{2}$ \\ ${ }^{1}$ Interdepartmental Center for Research in Environmental Science (CIRSA) \\ University of Bologna, Ravenna, Italy \\ ${ }^{2}$ LnuC EEMiS - Marine Ecology, Linnaeus University, Kalmar, Sweden
}

\begin{abstract}
The haptophyte Prymnesium parvum has a worldwide distribution, with dramatic increase in blooms in the last years. P. parvum blooms are often associated with massive fish kills and great ecological impacts and economic losses as a consequence. $P$. parvum is a mixotrophic organism, utilizing organic dissolved substances and particles to support its photosynthetic growth. The ability of $P$. parvum to produce toxic compounds, and being a mixotroph, makes it capable to outcompete other algal species for essential substances. These mechanisms are mostly enhanced when environmental conditions are not optimal for $P$. parvum growth. Here we report results on the growth, toxicity and mixotrophy, from experiments where $P$. parvum cells were grown as monocultures or together with Rhodomonas salina and exposed to different light conditions (dark, 100, 700, $2000 \mu \mathrm{mol}$ photons $\mathrm{m}^{-2} \mathrm{~s}^{-1}$ ). The results showed that $P$. parvum growth is affected at light intensity of $700 \mu \mathrm{mol}$ photons $\mathrm{m}^{-2} \mathrm{~s}^{-1}$ and the cells were photo-lysed when exposed to irradiances above this value. An inverse relationship between cellular toxicity and light intensity was observed, i.e. lower light irradiation induced higher cell toxicity. Phagotrophy was observed in all the conditions. $P$. parvum reached significantly higher cell densities when growing together with $R$. salina than in monocultures, while cellular toxicity was significantly reduced in the mixed cultures. Furthermore the presence of prey attenuated the negative effect of the higher irradiations on $P$. parvum growth.
\end{abstract}

\section{KEYWORDS}

Prymnesium parvum, irradiance, mixotrophy, growth, toxicity

\section{INTRODUCTION}

The haptophyta Prymnesium parvum has been responsible for toxic blooms throughout the world, with massive fish kills and great ecological impacts and economic losses [4, 13, 24, 2]. P. parvum 
is known to produce prymnesins 1 and 2 (polyoxy-polyene-polyethers) and several other compounds which are not chemically identified, but with cytotoxic, hemolytic, neurotoxic or ichthyotoxic properties $[17,15,23,28]$. The production of Prymnesium toxins is enhanced when cells grow under stress conditions, such as nutrient deficiency, sub-optimal temperature, salinity, and light conditions $[26,7,12,27]$. These toxins have a negative effect on other algal species and grazers, which may give $P$. parvum a competitive advantage when e.g. abiotic factors are limiting its growth $[5,9,10,20]$. Furthermore, since $P$. parvum is a mixotrophic organism it can utilize organic particles (phagotrophy to acquire macronutrients) [3, 1, 19], or dissolved organic substances (osmotrophy) to support its photosynthetic growth [22, 21].

Since $P$. parvum bloom formation is a recurring problem in many aquatic systems, a considerable effort has been devoted in developing mitigation measures. Some of the proposed mitigation methods involves alteration of water quality; e.g. nutrient manipulation, ozonation which can have negative effects on non-target organisms. Light intensity is one of the main factors that directly influence $P$. parvum growth and toxicity $[12,11]$. Therefore it is worth considering the possibility of using light as technique to minimize the negative effects of $P$. parvum. Thus present study was conducted with aims of studying; (1) the effect of different light intensities on Prymnesium parvum growth and toxicity; (2) if extremely high light exposition has an effect on P. parvum toxicity, does the availability of prey (i.e. $R$. salina) also change the toxin production under these extreme conditions?

\section{MATERIALS AND METHODS}

Non-axenic monocultures of Rhodomonas salina and Prymnesium parvum (KAC 30 and KAC 39, Kalmar Algae Collection, Linnaeus University, Sweden) were grown as batch cultures in modified $\mathrm{f} / 2(\mathrm{~N}=580 \mu \mathrm{M}$ and $\mathrm{P}=36.3 \mu \mathrm{M})$ and $\mathrm{P}$ limited $\mathrm{f} / 10(\mathrm{~N}=116 \mu \mathrm{M}$, and $\mathrm{P}=5.8 \mu \mathrm{M})$ media respectively [14]. Culture media were prepared with filtered (Whatman GF/C) and autoclaved aged Baltic Sea water (salinity $7 \mathrm{psu}$ ). Cultures were grown at a light intensity of 100 $\mu \mathrm{mol}$ photons $\mathrm{m}^{-2} \mathrm{~s}^{-1}, 16: 8$ light-dark (L:D) cycle, and at $20^{\circ} \mathrm{C}$. The experiment started when the stock cultures reached high cell densities and were still growing exponentially. Three treatments were used for the experiment, i.e. $P$. parvum monoculture, $R$. salina monoculture and a mixed culture of both microalgae, where cell densities of $P$. parvum $: R$. salina were $2: 1$. Initial cell densities of $P$. parvum and $R$. salina were $3.88 \times 10^{5}$ and $2.10 \times 10^{5}$ cells $\mathrm{ml}^{-1}$ in both monoculture and mixed culture treatments. Initial culture volumes of $300 \mathrm{ml}$ from each treatment in $500 \mathrm{ml}$ glass bottles (Schott Duran), in triplicates, were exposed to three light intensities: 100, 700, $2000 \mu \mathrm{mol}$ photons $\mathrm{m}^{-2} \mathrm{~s}^{-1}$ with 16:8 L:D cycle (cool white lamps, Osram Powerstar HQI-E $250 \mathrm{WD}$ ) and one treatment to darkness. The experiment was conducted at $20{ }^{\circ} \mathrm{C}$ and lasted 4 days.

Cell growth was followed using flow cytometry (FACSCalibur flow cytometer, Becton Dickinson) and maximum specific growth rates $\left(\right.$ day $\left.^{-1}\right)$ were calculated using the formula;

$\mu=\left(\ln \mathrm{N}_{2}-\ln \mathrm{N}_{1}\right) /\left(\mathrm{t}_{2}-\mathrm{t}_{1}\right)$, in which $\mathrm{N}_{1}$ and $\mathrm{N}_{2}$ are total cell concentrations at $\mathrm{t}_{1}$ and $\mathrm{t}_{2}$, (days) respectively. Hemolytic test on the cells methanolic extracts were used to determine intracellular toxicity and the results were expressed as ng saponin equivalent per cell $\left(\mathrm{SnEq}\right.$ cell $\left.^{-1}\right)$ [16]. The supernatants were also tested for hemolytic activity to determine the presence of extracellular toxins. Live observations of the cells were made using an inverted microscope (Olympus CKX 41) and epifluorescence microscope to determine phagotrophy in P. parvum. 


\section{RESULTS AND DISCUSSION}

\subsection{Growth of Prymnesium parvum and Rhodomonas salina}

Growth of $P$. parvum exposed to 700 and $2000 \mu \mathrm{mol}$ photons $\mathrm{m}^{-2} \mathrm{~s}^{-1}$ was found to decrease rapidly and the cells were totally photo-lysed after $4 \mathrm{~h}$ of being exposed to $2000 \mu \mathrm{mol}$ photons $\mathrm{m}^{-}$ ${ }^{2} \mathrm{~s}^{-1}$ (Figure 1). The maxima biomass levels and higher growth rates were found for the cultures exposed to $100 \mu \mathrm{mol}$ photons $\mathrm{m}^{-2} \mathrm{~s}^{-1}(\mathrm{~F}=192.01, \mathrm{p}<0.05)$ which represent the optimal light intensity for $P$. parvum growth among the conditions used in our study. Growth rates and maximum biomass levels of $P$. parvum were always higher when grown in mixed cultures compared to those found in the monocultures at corresponding light intensities. Furthermore $P$. parvum survived for a longer time when grown in mixed cultures than when growing as monocultures. These shows that $P$. parvum needs to ingest organic matter in order to thrive and achieve higher biomass. As observed in other studies, the ingestion of $R$. salina contributed to increase the growth rate and biomass of $P$. parvum cells $[19,5,9,29]$.

$R$. salina lasted longer $(10-26 \mathrm{~h})$ than $P$. parvum when exposed to high light intensities (700 and $2000 \mu \mathrm{mol}$ photons $\mathrm{m}^{-2} \mathrm{~s}^{-1}$ ) showing that $R$. salina is more adapted to higher light intensities than $P$. parvum to grow (Figure 1). R. salina monocultures reached the highest cell densities (5.25 \pm 0.16 and $\left.5.13 \pm 0.21 \times 10^{5} \mathrm{cells} \mathrm{ml}^{-1}\right)$ and maximum specific growth rates $(0.63 \pm 0.07$ and $0.63 \pm$ $\left.0.08 \mathrm{~d}^{-1}\right)$ at 100 and $700 \mu \mathrm{mol}$ photons $\mathrm{m}^{-2} \mathrm{~s}^{-1}$

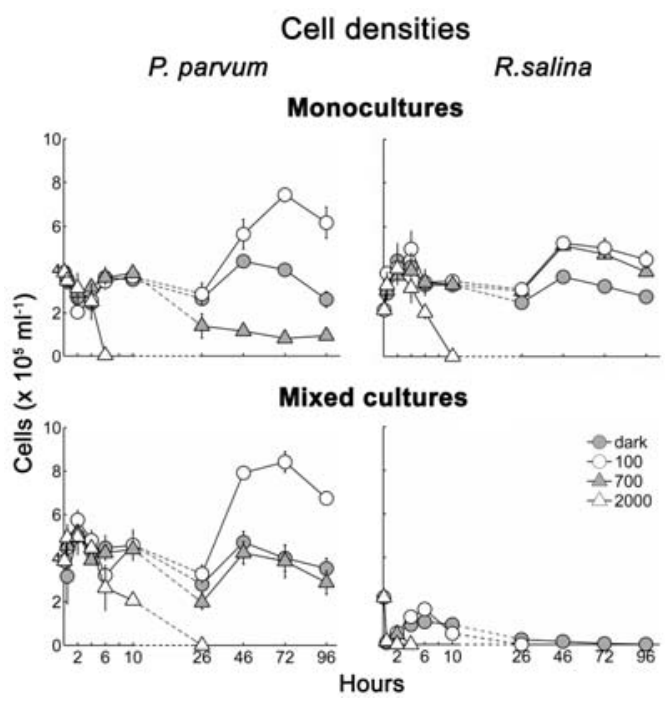

Figure 1. Growth of mono (P. parvum and R. salina) and mixed cultures, exposed to 4 light conditions: dark, 100, 700 and 2000 umol photons $\mathrm{m}^{-2} \mathrm{~s}^{-1}$.

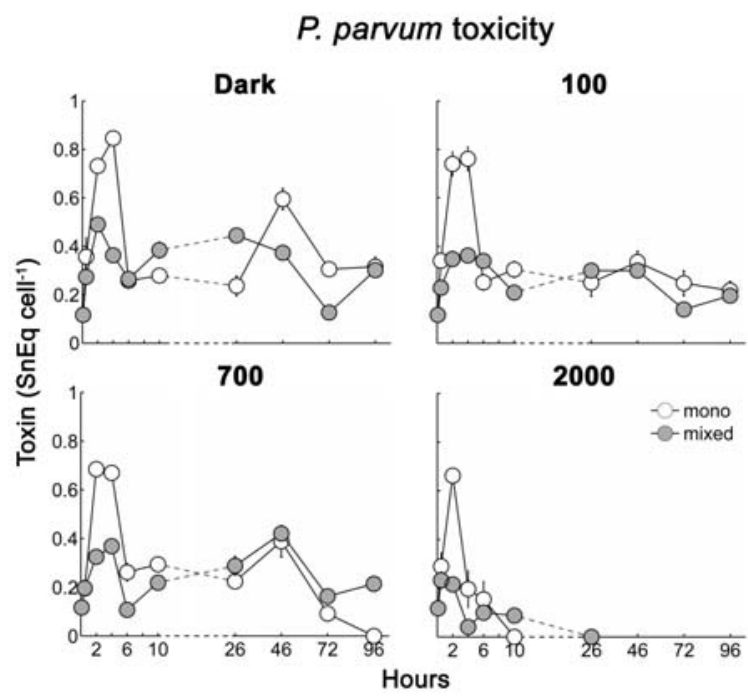

Figure 2. P. parvum cellular toxicity $\left(\mathrm{SnEq} \mathrm{cell}^{-1}\right)$ measured in mono and mixed cultures grown at different light conditions: dark, 100, 700, $2000 \mu \mathrm{mol}$ photons $m^{-2} s^{-1}$. 
$R$. salina cells densities on the other hand decreased rapidly when grown in mixed cultures indicating that they were being eaten by $P$. parvum cells. When exposed to high light intensities (700 and $2000 \mu$ mol photons $\mathrm{m}^{-2} \mathrm{~s}^{-1}$ ) $R$. salina completely disappeared after only $2-3 \mathrm{~h}$, while at $100 \mu \mathrm{mol}$ photons $\mathrm{m}^{-2} \mathrm{~s}^{-1}$ and in dark conditions it survived up to $46 \mathrm{~h}$ and $96 \mathrm{~h}$, respectively.

\subsection{Prymnesium parvum toxicity}

In our experiment, the light condition under which the maximum P. parvum cell densities were reported $\left(100 \mu \mathrm{mol}\right.$ photons $\left.\mathrm{m}^{-2} \mathrm{~s}^{-1}\right)$ did not coincide with that for toxin production (darkness). Of all the conditions tested, the highest cell toxicities $\left(0.85 \pm 0.03 \mathrm{SnEq}\right.$ cell $\left.^{-1}\right)$ were found in the monocultures kept in continuous darkness and these levels were significantly $(\mathrm{F}=36.9, \mathrm{p}<0.05)$ higher than those obtained when $P$. parvum cells were exposed to light irradiance $(100,700$ and $2000 \mu \mathrm{mol}$ photons $\mathrm{m}^{-2} \mathrm{~s}^{-1}$ ). In the treatments where $P$. parvum was exposed to light irradiance, higher toxicities was found at $100 \mu \mathrm{mol}$ photons $\mathrm{m}^{-2} \mathrm{~s}^{-1}$ while at 700 and $2000 \mu \mathrm{mol}$ photons $\mathrm{m}^{-2}$ $\mathrm{s}^{-1}$, the toxins were rapidly destroyed (fig. 2).

The maximum toxicity levels were significantly lower in the mixed cultures than in the monocultures $(\mathrm{F}=1172.2, \mathrm{p}<0.05)$. This indicates that in the mixed cultures $P$. parvum was obtaining more nutrients to grow (ingestion of $R$. salina cells) than in the monocultures, confirming previous results of several authors $[8,12]$. Toxicity maxima results were opposed to the findings on the growth. When in mixed cultures, P. parvum increased the growth while producing low levels of toxins. This indicates that when the conditions are optimal for the growth P. parvum produce less toxin per cell [10].

Extracellular toxicity in the media was not detectable by the haemolytic toxicity assay we used. However $R$. salina cell densities decreased due to the combined effect of grazing and release of toxins by $P$. parvum. Thus, the decreases of $R$. salina cell densities in the mixed cultures compared to the monocultures could be used as an indicator of extracellular toxicity. We observed that $R$. salina cell densities decreased faster at high light intensities (700 and $2000 \mu \mathrm{mol}$ photons $\mathrm{m}^{-2} \mathrm{~s}^{-1}$ ) than at $100 \mu \mathrm{mol}$ photons $\mathrm{m}^{-2} \mathrm{~s}^{-1}$ and/or in darkness. For example $R$. salina cell densities in the mixed cultures decreased up to $-83.8 \pm 27.5$ and $-99.7 \pm 14.9 \%$ (respectively at 700 and $2000 \mu \mathrm{mol}$ photons $\mathrm{m}^{-2} \mathrm{~s}^{-1}$ ) compared to the initial cell densities, at time $2 \mathrm{~h}$ after the start of the experiment. This indicates that the measured toxins in supernatant in these treatments were probably being released into the media by the damaged $P$. parvum cells in the by the higher light irradiations, and not higher production of haemolytic compounds being produced by $P$. parvum. Excretion of toxins into the media by P. parvum can occur even when the cells are growing under optimum conditions, however the amounts of toxins being excreted is usually much lower than when $P$. parvum cells are in stress conditions; e.g. high light irradiances, deficient $\mathrm{N}$ and $\mathrm{P}$ conditions, etc. In fact microscopic observations clearly showed toxic effects of Prymnesium parvum on Rhodomonas salina at all light conditions. As soon as the two algae were mixed together, $R$. salina cells were lysed and rapidly attacked by several $P$. parvum cells, which formed large aggregates around the former before ingesting it.

Thus, we suggest that at high light intensities, $P$. parvum cells were rapidly photo-lysed releasing the toxins in the medium. $R$. salina was affected by these released toxins before the toxins were degraded by the high light intensities. Released toxins require a certain period of time to be photo-degradet which depends on the quality and the intensity of the light to which they are being exposed to $[25,6,18]$. 


\section{CONCLUSION}

Our results support the hypothesis that in light stress conditions (700 and $2000 \mu \mathrm{mol}$ photons $\mathrm{m}^{-2}$ $\mathrm{s}^{-1}$ ) P. parvum toxins are released in the medium due to photo-lysis of the cells. This process caused an increase of extracellular toxicity that rapidly killed $R$. salina cells during the first hours of the experiment at light intensities above $700 \mu \mathrm{mol}$ photons $\mathrm{m}^{-2} \mathrm{~s}^{-1}$. Although high light intensities inhibited $P$. parvum growth and reduced its hemolytic responses, we conclude that extracellular toxicity is significantly enhanced (destruction of $P$. parvum cells) at light intensity of $700 \mu \mathrm{mol}$ photons $\mathrm{m}^{-2} \mathrm{~s}^{-1}$ and above this level, thereby the death of the co-occurring species occurs as toxicity in the medium increases. Thus use of high light intensities as a mitigation method need more studies specially focusing on the effects on other species such as co-occurring non-toxic phytoplankton Species.

\section{REFERENCES}

[1] Arenovski, A.L., Lim, E.L., Caron D.A., 1995. Mixotrophic nanoplancton in oligotrophic surface water of the Sargasso Sea may employ phagotrophy to obtain major nutrients. J. Plankton. Res. 17, 801-820.

[2] Brooks, B.W., Grover, J.P., Roelke, D.L., 2011. Prymnesium parvum: an emerging threat to inland waters. Environmental toxicology and chemistry 30, 1955-1964.

[3] Caron, D.A., Sanders, R.W., Lin Lim, E., Marrasè, C., Amaral, L.A., Whitney, S., Aoki, R.B., Porter, K.G., 1993. Light-dependent phagotropy in fresh water mixotrophic chrysophyte Dinobryon cylindricum. Microbilal Ecology. 25, 93-111.

[4] Edvardsen, B., Paasche, E., 1998. Bloom dynamics and physiology of Prymnesium and Chrisochromulina. In Anderson, D.M., Cembella, A.D., Hallegraeff, G.M. (Eds.) Physiological ecology of Harmful Algal Blooms, Springer-Verlag, Berlin, pp. 193-208.

[5] Fistarol, G.O., Legrand, C., Granéli, E., 2003. Allelopathic effect of Prymnesium parvum on a natural plankton community. Marine Ecology Progress Series 255, 115-125.

[6] Freitag, M., Beszteri, S., Vogel, H., John, U., 2011. Effect of physiological shock treatments on toxicity and poliketide synthase gene expression in Prymnesium parvum (Prymnesiophyceae). European Journal of Phycology 46, 193-201.

[7] Granéli, E., Flynn, K., 2006. Chemical and physical factors influencing toxin content. In: Ecology of Harmful Algae, E. Granéli, and J.T. Turner (Editors). Ecological Studies, Vol. 189. Springer Verlag, Berlin, Heidelberg, Germany, pp. 189-201.

[8] Granéli, E., Johansson, N., 2001. Nitrogen or phosphorus deficiency increases allelopathy in Prymnesium parvum. In Hallegraeff GM, Blackburn SI, Bolch CJ, Lewis RJ (eds.) Harmful Algal Blooms 2000. Intergov Oceanografic Commission of UNESCO, pp. 328-331

[9] Granéli, E., Johansson, N., 2003a. Effects of the Toxic Haptophyte Prymnesium parvum on the survival and feeding of a ciliate: The influence of different nutrient conditions. Marine Ecology Progress Series 254, 49-56.

[10] Granéli, E., Johansson, N., 2003b. Increase in the production of allelopathic substances by Prymnesium parvum cells grown under N- or P-deficient conditions. Harmful Algae 2, 135145.

[11] Granéli, E., Salomon, P.S., 2010. Factors influencig allelopathy and toxicity in Prymnesium parvum. Journal of the American Water Resources Association 46, 108-120.

[12] Granéli, E., Edvardsen, B., Roelke, D.L., Hagström, J.A., 2012. The ecophysiology and bloom dynamics of Prymnesium spp. Harmful Algae 14:260-270 
[13] Granéli, E., Paasche, E., Maestrini, S.Y., 1993. Three years after the Chrysochromulina polylepis bloom in Scandinavian waters in 1988: some conclusions of recent research and monitoring. In: Smayda TJ, Shimizu Y (eds) Toxic Phytoplankton Blooms in the Sea. Elsevier, Amsterdam, pp. 23-32

[14] Guillard, R.R., Ryther, J.H., 1962. Studies of marine planktonic diatoms .I. Cyclotella nana Husted, and Detonula confervacea (cleve) Gran. Canadian Journal of Microbiology 8, 229-39

[15] Henrikson, J.C., Gharfeh, M.S., Easton, A.C., Easton, J.D., Glenn, K.L., Shadfan, M., Mooberry, S.L., Hambright, K.D., Cichewicz, R.H., (2010). Reassessing the ichthyotoxin profile of cultured Prymnesium parvum (golden algae) and comparing it to samples collected from recent freshwater bloom and fish kill events in North America. Toxicon, 55, 1396-1404.

[16] Igarashi, T., Aritake, S., Yasumoto, T., 1998. Biological activities of prymnesin-2 isolated from a red tide alga Prymnesium parvum. Nar. Toxins 6: 35-41.

[17] Igarashi, T., Oshima, Y., Murata, M., Yasumoto, T., 1995. Chemical studies on prymnesins isolated from Prymnesium parvum. In: Harmful Marine Algal Blooms: Proceedings of the sixth Iternational Conference on toxic marine phytoplankton, October 1993, Nantes, France, P. Lassus, G. Arzul, E. Erard-Le Denn, P. Gentier, C. Marcaillou- Le Baut (Editors). Lavoisier Pubblishing, Paris, France, pp. 303-308.

[18] James, S. V., Valentini, T.W., Prosser, J.K.N., Grover, J.P., Roelke, D.L., 2011. Sunlight amelioration of Prymnesium parvum acute toxicity to fish. Journal of Plankton Research 33, $265-272$.

[19] Legrand, C., Johansson, N., Johnsen, G., Børsheim, K.Y., Granéli, E., 2001. Phagotrophy and toxicity variation in the mixotrophic Prymnesium patelliferum (Haptophyceae). Limnol. Oceanogr. 46, 1208-1214.

[20 Legrand, C., Rengefors, K., Fistarol, G.O., Granéli, E., 2003. Allelopathy in phytoplankton: biochemical, ecological and evolutionary aspects. Phycologia 42, 406-419.

[21] Lindehoff, E., Granéli, E., Glibert, P., 2011. Nitrogen uptake kinetics of Prymnesium parvum (Haptophyte). Harmful Algae 12, $70-76$.

[22] Lindehoff, E., Granéli, E., Granéli, W., 2009. Effect of tertiary sewage effluent additions on Prymnesium parvum cell toxicity and stable isotope ratios. Harmful Algae 8, 247-253.

[23] Manning, S. R., La Claire II, J. W., 2010. Prymnesins: toxic metabolites of the golden alga, Prymnesium parvum Carter (Haptophyta). Marine Drugs 8, 678-704.

[24] Morohashi, A., Satake, M., Oshima, Y., Igarashi, T., Yasumoto, T., 2001. Absolute configuration at C14 and C85 in Prymnesin-2, a potent hemolytic and ichthyotoxic glycoside isolated from the red tide alga Prymnesium parvum. Chirality 13, 601-605.

[25] Parnas, I., Reich K., Bergmann F., 1962. Photoinactivation of Ichthyotoxin from Axenic Cultures of Prymnesium parvum Carter. Appl. Microbiol. 10, 237-239.

[26] Reich, K., Parnas, I., 1962. Effect of illumination of ichthyotoxin in an axenic culture of Prymnesium parvum Carter. J.Protozool. 9, 38-40.

[27] Roelke, D. L., Grover, J. P., Brooks, B. W., 2011. A decade of fish-killing Prymnesium parvum blooms in Texas: roles of inflow and salinity. Journal of Plankton Research 33, 243253.

[28] Schug, K. A., Skingel, T. R., Spencer, S. E., Serrano, C. A., Le, C. Q., Schug, C. A., Valentini, T. W., Brooks, B. W., Mydlarz, L. D., Grover, J. P., 2010. Hemolysis, fish mortality, and LC-ESI-MS of cultured crude and fractionated golden alga (Prymnesium parvum). J. Am. Water Resour. Assoc. 68, 2059-2067.

[29] Tillmann, U., 2003. Kill and eat your predator: a winning strategy of the planktonic flagellate Prymnesium parvum. Aquat. Microb. Ecol. 32, 73-84. 